\title{
PERAN KETERLIBATAN PRODUK DALAM MEMODERASI HUBUNGAN ANTARA KUALITAS LAYANAN DARING TERHADAP KEPUASAN DARING
}

\author{
Miftahul Jannah ${ }^{1}$ \\ Sahid Susilo Nugroho ${ }^{2}$ \\ Indriyo Gitosudarmo ${ }^{3}$
}

\begin{abstract}
${ }^{1}$ Fakultas Ekonomi dan Bisnis, Universitas Trunojoyo Madura, Madura, Indonesia, mitahuljannah017@gmail.com,08193151917.

${ }^{2}$ Fakultas Ekonomika dan Bisnis, Universitas Gadjah Mada, Yogyakarta, Indonesia, sahid@ugm.ac.id,081227090000

${ }^{3}$ Fakultas Ekonomika dan Bisnis, Universitas Gadjah Mada, Yogyakarta, Indonesia, indriyogito@yahoo.com,
\end{abstract}

\begin{abstract}
The Role of Product Involvement in Moderating the Relationship Between Online Service Quality and Online Satisfaction. The moderating effect of product involvement on the relationship between e-service quality and e-satisfaction. This study is aimed to examine the effect of five dimensions of e-service quality: (1) website design, (2) reliability, (3) customer service, (4) security/privacy, and (5) after sales service, on e-satisfaction and e-loyalty. The study also analyzed the moderating effects of product involvement on the relationship between e-service quality and e-satisfaction. A quantitative study approach using survey method is adopted to reach 228 respondents. The data is analyzed by simple, multiple, and hierarchical regression methods to explore direct and moderating effect among intended variables. The study findings confirmed that reliability, customer service, and after sales service have influenced e-satisfaction.
\end{abstract}

Keywords: e-service quality; e-satisfaction; product involvement.

\begin{abstract}
Abstrak: Peran Keterlibatan Produk Dalam Memoderasi Hubungan Antara Kualitas Layanan Daring Terhadap Kepuasan Daring. Pengaruh moderasi keterlibatan produk pada hubungan antara kualitas layanan daring dan kepuasan daring. Studi ini memiliki dua tujuan. Tujuan pertama menguji pengaruh lima dimensi kualitas layanan daring yakni meliputi: (1) desain laman, (2) reliabilitas, (3) layanan pelanggan, (4) keamanan/privasi, dan (5) layanan pelanggan pasca pembelian, pada kepuasan daring dan loyalitas daring. Tujuan kedua menguji pengaruh moderasi dari tingkat keterlibatan produk pada hubungan antara lima dimensi kualitas layanan dan kepuasan daring. Studi dilakukan dengan pendekatan kuantitatif melalui metode survei. Proses pengumpulan data dilakukan secara daring dan luring dengan ukuran sampel sejumlah 228 responden. Metode analisis data yang digunakan untuk menguji hubungan antar variabel dalam studi ini adalalah analisis regresi. Temuan studi menunjukkan bahwa hanya tiga dimensi kualitas layanan daring yakni: (1) reliabilitas, (2) layanan pelanggan, dan (3) layanan pelanggan pasca pembelian yang terbukti berpengaruh pada kepuasan daring. Kemudian studi juga mengkonfirmasi pengaruh kepuasan daring pada loyalitas daring. Selanjutnya studi membuktikan bahwa keterlibatan produk berhasil memoderasi hubungan antara lima dimensi kualitas layanan daring dan kepuasan daring.
\end{abstract}

Kata Kunci: kualitas layanan daring; kepuasan daring; keterlibatan produk. 


\section{PENDAHULUAN}

Berdasarkan ranking web metrik yang dilaporkan oleh laman alexa.com (2019), Tokopedia dan Bukalapak adalah dua laman belanja daring paling terpopuler di Indonesia pada saat ini. Banyaknya laman belanja daring yang aktif melayani pasar Indonesia, membuat setiap perusahaan harus bekerja keras untuk membangun loyalitas konsumen. Mempertahankan loyalitas pada perdagangan daring lebih rumit dibandingkan pada konteks perdagangan luring (Chang \& Wang, 2011). Keberhasilan mempertahankan loyalitas konsumen ditentukan oleh kinerja perusahaan dalam memuaskan pelanggan (Anderson \& Srinivasan, 2003). Kepuasan pelanggan tidak hanya ditentukan oleh kualitas laman belanja daring dan harga yang murah, tetapi juga sangat dipengaruhi oleh kualitas layanan daring yang diberikan (Zeithaml et al., 2002; Jayawardhena \& Wright, 2009). Kualitas layanan daring memiliki karakteristik berbeda dengan kualitas layanan luring. Layanan pada perdagangan daring bersifat virtual, swalayan, dan tidak dibatasi oleh hari kerja dan jam operasi layanan. Dengan demikian tuntutan kualitas layanan daring menjadi relatif lebih tinggi dibandingkan layanan luring (Ansari et al., 2008).

Studi berhasil mengidentifikasi tiga kesenjangan riset berkaitan dengan topik pengaruh kualitas layanan daring pada kepuasan daring dan loyalitas daring. Kesenjangan pertama adalah kesenjangan teoritis terkait dimensi pengukuran kualitas layanan daring. Penelitian mengenai kualitas layanan daring selama ini banyak menggunakan dimensidimensi pengukuran yang menekankan pada aspek layanan pada saat sebelum dan saat proses pembelian berlangsung. Momentum pasca pembelian ketika konsumen mengalami kegagalan layanan, justru tidak banyak mendapatkan perhatian dari para peneliti (Piercy, 2014). Terkait dengan kritik ini, Zeithaml et al. (2002) dan Parasuraman et al. (2005) mencoba mengakomodasi situasi kegagalan layanan dengan mempertimbangkan respon perusahaan terhadap konsumen bermasalah yakni: (1) daya tanggap, (2) kontak, dan (3) kompensasi. Namun demikian, kedua studi tersebut tetap mendapat kritikan dari Yen dan Lu ( 2008), karena dianggap mengabaikan kebutuhan layanan pelanggan secara umum pada saat proses pembelian berlangsung. Layanan konsumen semestinya tidak hanya dibutuhkan oleh konsumen bermasalah, tetapi juga kepada semua konsumen (Rolland \& Freeman, 2010). Piercy (2014) menawarkan solusi menarik yakni bahwa perlu dilakukan pemisahan antara dimensi pelaksanaan layanan dan pemulihan layanan. Selain itu, pengukuran kualitas layanan seharusnya juga memperhitungkan semua proses transaksi sampai pada tahap kemungkinan terjadinya transaksi retur pembelian (Rolland \& Freeman, 2010). Oleh karena itu, Rolland dan Freeman (2010) mengajukan dimensi layanan pelanggan pasca pembelian yakni: (1) retur dan (2) refund.

Kesenjangan riset kedua adalah kesenjangan teoritis terkait keberadaan variabel pemoderasi pada hubungan antara kualitas layanan daring dan kepuasan pelanggan. Studi mengenai pengaruh kualitas layanan daring pada kepuasan pelanggan masih bisa diperkaya dengan memunculkan variabel pemoderasi yang relevan. Janda et al. (2002), serta Chang dan Chen (2009) mengajukan variabel keterlibatan produk sebagai variabel pemoderasi yang sifatnya memperkuat pengaruh kualitas layanan daring pada kepuasan pelanggan. Preposisi ini mempertimbangkan bahwa keterlibatan produk merupakan faktor penentu utama pada perilaku pembelian perdagangan daring karena variasi keterlibatan produk akan menghasilkan perbedaan respon dari para konsumen $(\mathrm{Wu}$, 2002). Preposisi tersebut juga memiliki nilai penting karena studi keperilakuan konsumen terkait keterlibatan produk dalam perdagangan daring relatif masih terbatas (Hong, 2015).

Kesenjangan riset ketiga adalah kesenjangan empiris terkait ketidakkonsistenan 
hasil-hasil temuan studi terdahulu mengenai pengaruh dimensi-dimensi kualitas layanan daring pada kepuasan pelanggan. Berikut ini adalah 3 contoh kontroversi temuan studi yakni: (1) keamanan, (2) daya tanggap, (3) reliabilitas dan kepuasan pelanggan. Studi Wolfinbarger dan Gilly (2003) membuktikan bahwa dimensi keamanan tidak berpengaruh pada kepuasan pelanggan. Temuan tersebut berbeda dengan temuan studi oleh Chang dan Chen (2009) yang justru mengkonfirmasi bahwa keamanan berpengaruh positif pada kepuasan pelanggan. Studi Sakhaei et al. (2014) membuktikan bahwa daya tanggap berpengaruh postif pada kepuasan pelanggan. Namun sebaliknya, studi Kim et al., (2009) justru mengkonfirmasi bahwa daya tanggap tidak berpengaruh pada kepuasan pelanggan. Studi Sahadev dan Purani (2008) menemukan bahwa reliabilitas tidak berpengaruh pada kepuasan pelanggan. Temuan ini bertolak belakang dengan temuan studi Lee dan Lin (2005) yang menunjukkan bahwa reliabilitas berpengaruh positif pada kepuasan pelanggan. Terjadinya hasil temuan yang berbeda-beda sebagaimana dijelaskan di atas diduga disebabkan oleh perbedaan setting penelitian dari setiap studi terkait.

Studi ini bertujuan menguji pengaruh dimensi-dimensi kualitas layanan pada kepuasan daring dan loyalitas daring. Kepuasan daring dalam konteks ini juga berperan sebagai variabel pemediasi pada hubungan antara dimensi-dimensi kualitas layanan daring dan loyalitas. Selanjutnya, studi juga menguji peran keterlibatan produk sebagai variabel pemoderasi yang memperkuat hubungan positif antara kualitas layanan dan kepuasan.

Loyalitas pada konteks perdagangan daring berbeda dengan loyalitas pada konteks perdagangan luring. Loyalitas daring didefinisikan sebagai niat konsumen untuk melakukan pembelian ulang, kecenderungan untuk memberikan getok tular, memberikan toleransi harga, serta kecenderungan untuk melakukan pembelian silang dari perusahaan yang sama (Boulding et al., 1993). Shankar et al. (1999) menyatakan bahwa loyalitas pada perdagangan daring lebih terfokus pada attitudinal loyalty sebagaimana dikemukakan oleh Oliver (1999). Pada studi ini loyalitas yang diukur adalah loyalitas yang didasari oleh niat konsumen untuk melakukan pembelian kembali kepada perusahaan yang sama dan bersedia untuk memberikan rekomendasi yang positif kepada orang lain.

Kepuasan daring (e-satisfaction) dimaknai oleh Syzmansky dan Hise (2000) sebagai sebuah judgment konsumen terhadap hasil perbandingan antara pengalaman konsumen dalam pembelian daring dan pengalaman serupa pada pembelian luring. Pendapat ini didukung Anderson dan Srinivasan (2003) yang juga mengartikan kepuasan daring sebagai bentuk kesenangan yang dirasakan konsumen dengan memperhatikan pengalaman pembelian sebelumnya pada perusahaan penjual produk dalam perdagangan daring. Pengertian tersebut semakin diperkuat oleh Kim et al., (2009) yang menyatakan bahwa kepuasan daring adalah sebuah konstruk kumulatif berdasarkan nilai kepuasan yang terjadi pada setiap pembelian dan pengalaman konsumsi dengan barang dan jasa dari waktu ke waktu.

Tingkat keterlibatan produk yang dimiliki konsumen dipandang sangat menentukan keberhasilan pemasaran produk berbasis internet (Wu, 2002), karena hal itu menjadi faktor yang menyebabkan perbedaan respon konsumen pada proses keputusan pembelian. Loudon dan Bitta dalam Wu (2002) menyatakan bahwa terdapat tiga respon yang akan menjadi berbeda karena adanya fenomena keterlibatan produk yaitu pada tahap pencarian informasi, pengolahan informasi, dan pengambilan keputusan pembelian.

Zaichkowsky (1985) menjelaskan keterlibatan produk adalah sebuah persepsi konsumen terhadap sebuah obyek berbasis kebutuhan yang melekat, nilai, dan ketertarikan secara individual. Penjelasan Zaichkowsky 
(1985) tersebut dianggap belum lengkap karena tidak memasukkan faktor risiko sebagaimana yang dijelaskan oleh Kapferer dan Laurent (1985). Bauer dalam Kapferer dan Laurent (1985) menyatakan bahwa keterlibatan produk sangat berkaitan erat dengan risiko yang dihadapi konsumen sebagai misal risiko kesalahan pembelian. Kapferer dan Laurent (1985) selanjutnya menjabarkan keterlibatan produk sebagai keluaran dari lima faktor pembentuk: (1) ketertarikan, (2) nilai kesenangan (hedonic value), (3) nilai yang berkaitan dengan status diri (sign value), (4) kemungkinan risiko terjadinya kesalahan pembelian, dan (5) tingkat kepentingan risiko sebagai konsekuensi kesalahan pembelian,

Kualitas layanan daring (e-service quality) adalah suatu bentuk evaluasi pelanggan secara keseluruhan mengenai kualitas penyampaian layanan daring pada pasar virtual (Santos, 2003). Perdagangan daring merupakan proses yang kompleks yang membagi transaksi menjadi berbagai tingkatan proses mencakup navigasi website, pencarian informasi tertentu, negosiasi, pembayaran daring, pengiriman barang, serta layanan pasca pembelian (Yen \& $\mathrm{Lu}, 2008)$. Kualitas layanan daring tidak hanya dari evaluasi pada sistem secara komprehensif, namun juga menyangkut hal-hal teknis yang menjadi esensi pelayanan yakni pengiriman barang dan layanan pasca pembelian. Zeithaml et al. (2002) menyatakan bahwa kualitas layanan daring menunjukkan sejauh mana sebuah laman mampu memfasilitasi proses pembelanjaan, pembelian, dan pengiriman produk secara efektif dan efisien.

Wolfinbarger dan Gilly (2001) menyatakan bahwa ketersediaan informasi pada sebuah laman merupakan aspek penting pada perdagangan daring. Kualitas layanan laman akan dinilai konsumen sejak tahap pencarian informasi dilakukan melalui sistem navigasi dan tampilan visual yang terstruktur (Bauer et al., 2006). Szymanski dan Hise (2000) menyatakan bahwa laman yang baik mencerminkan kesan perusahaan yang baik pula. Ketika perusahaan mampu memberikan informasi yang cukup, tersedia secara bebas, serta terorganisasi baik, maka 3 hal tersebut menjadi alasan kuat konsumen melakukan pembelian daring (Wolfinbarger \& Gilly, 2001). Dharmesti dan Nugroho (2012) menjelaskan bahwa desain laman yang baik dapat menjadikan konsumen nyaman dalam berbelanja dan kemudian menimbulkan kepuasan pelanggan. Studi oleh Chang et al., (2009) dan Kim et al. (2009) menemukan bahwa dimensi desain laman merupakan faktor terkuat pada kualitas layanan yang mampu mempengaruhi kepuasan pada perdagangan daring. Berdasarkan paparan tersebut maka dapat dihipotesiskan bahwa:

$H_{l a}$ : Desain laman berpengaruh positif pada kepuasan daring.

Reliabilitas dalam konteks perdagangan luring dapat didefinisikan sebagai kehandalan layanan dan akurasi pada informasi yang diberikan. Sedangkan pada konteks perdagangan daring, reliabilitas dimaknai sebagai kemampuan perusahaan memberikan layanan sesuai dengan yang dijanjikan seperti misalnya keberhasilan pengiriman produk secara tepat alamat, tepat waktu dan aman tanpa kerusakan (Ho \& Lee, 2007). Selanjutnya, Parasuraman et al. (2005) menyatakan bahwa kehandalan juga mengacu pada konsistensi kinerja perusahaan, sehingga konsumen bisa mengenali kredibilitas perusahaan. Reliabilitas atau kehandalan juga ditekankan pada tiga hal pokok: (1) ketepatan waktu pengiriman produk sebagaimana telah dijanjikan perusahaan kepada konsumen (Parasuraman et al., 2005; Zeithaml et al., 2002), (2) produk yang diterima konsumen harus sesuai dengan deskripsi yang dijelaskan pada penawaran perusahaan (Wolfinbarger \& Gilly, 2001), (3) produk yang diterima harus dengan permintaan atau spesifikasi yang ditentukan konsumen (Collier \& Bienstock, 2006). Studi oleh Chang et al., (2009) dan Santos (2003) mengkonfirmasi bahwa reliabilitas sebagai dimensi kualitas 
layanan terbukti berpengaruh pada kepuasan daring. Berdasarkan paparan tersebut maka dapat dihipotesiskan bahwa:

$H_{1 b}$ : Reliabilitas berpengaruh positif pada kepuasan daring.

Layanan

pelanggan adalah kemampuan perusahaan untuk memberikan informasi kepada pelanggan, kesediaan untuk membantu pelanggan, dan memberikan layanan yang cepat (Zeithaml, 2002). Layanan pelanggan dalam studi ini dibedakan antara layanan pelanggan secara umum dan layanan pelanggan saat konsumen mengalami kegagalan layanan. Layanan pelanggan secara umum mengacu pada daya tanggap dan kemudahan kontak secara daring (Parasuraman et al., 2005). Daya tanggap dalam hal ini diartikan sebagai layanan yang bersifat cepat dan bersedia menanggapi pertanyaan pelanggan (Gefen, 2003). Konsumen memberikan nilai positif pada perusahaan yang mampu memberikan layanan cepat dan saluran komunikasi memadai seperti misalnya email, nomor telepon, atau chat room. Layanan pelanggan yang baik akan memiliki dampak positif pada kepuasan (Kim et al., 2009; Chang et al. (2009). Semakin baik layanan yang diberikan perusahaan, maka konsumen semakin puas terhadap perusahaan tersebut. Berdasarkan pemaparan tersebut, maka dirumuskan hipotesis: $H_{I c}$ : Layanan pelanggan berpengaruh positif pada kepuasan daring.

Belanja daring secara teknis memiliki tingkat ketidakpastian yang relatif tinggi jika dibandingkan dengan belanja luring terkait dengan berbagai potensi risiko keamanan dan privasi yang ditanggung oleh konsumen (Suki \& Suki, 2007). Parasuraman et al. (2005) mendefinisikan keamanan/privasi sebagai sejauh mana laman perusahaan dinilai aman dan mampu melindungi informasi pribadi konsumen. Keamanan atau privasi dalam perdagangan daring dibedakan dari segi keuangan dan non keuangan. Keamanan Keuangan berkaitan dengan informasi seperti nomor rekening bank atau nomor kartu kredit. Sedangkan Keamanan
Non Keuangan berkaitan dengan informasi pribadi seperti tanggal lahir, alamat dan nomor telepon.

Jika konsumen mempersepsikan perusahaan mampu memberikan jaminan keamanan secara efektif, maka konsumen akan merasa nyaman saat berbelanja di sebuah toko daring. Rasa nyaman tersebut selajutnya akan menimbulkan kepuasan (Wagner \& Rydstrom, 2001). Studi oleh Yen dan Lu (2008) membuktikan bahwa keamanan atau privasi memiliki pengaruh positif terhadap proses diskonfirmasi yang kemudian mengarah pada tingkat kepuasan yang lebih tinggi. Berdasarkan penjelasan tersebut maka dapat dihipotesiskan: $H_{1 d}$ : Keamanan atau privasi berpengaruh positif pada kepuasan daring.

Kegagalan layanan daring bisa terjadi pada sebuah perusahaan dikarenakan kompleksitas aktivitas proses pembelian daring yang saling berkaitan (Li et al., 2013). Pertama kali perusahaan menyajikan informasi produk pada laman sedemikian rupa. Kemudian, konsumen melakukan keputusan pembelian berdasarkan deskripsi produk yang disajikan pada laman tersebut. Ketika konsumen telah menerima produk yang dibeli, maka keputusan final akan terjadi yaitu apakah konsumen akan menerima, atau menolak yang diikuti dengan pengembalian produk (Teo \& Yeong, 2003).

Kegagalan layanan terjadi ketika penawaran yang diberikan perusahaan mengalami kecacatan dalam bentuk informasi yang tidak akurat atau tidak lengkap (Xing et al., 2010), sehingga konsumen menderita kerugian secara keuangan ataupun nonkeuangan (Ha \& Jang, 2009). Proses perbaikan pada sebuah kegagalan layanan menjadi hal yang tidak mudah untuk dilakukan (Sengupta et al., 2015). Perusahaan perlu membangun kembali hubungan baik dengan konsumen melalui proses perbaikan layanan, atau memberikan penawaran pengembalian produk/ uang (Mattila, 2010; Xing et al., 2010). Jika konsumen mempersepsikan perusahaan mampu 
memberikan layanan perbaikan saat mengalami resiko kegagalan layanan, maka hal tersebut akan menimbulkan kepuasan konsumen yang lebih baik. Berdasarkan penjelasan tersebut, maka dapat dihipotesiskan:

$H_{1 e}:$ Layanan pelanggan pasca pembelian berpengaruh positif pada kepuasan daring.

Kepuasan dan loyalitas memiliki hubungan yang erat. Oliver (1999) dan Castaneda et al.(2009) menyatakan bahwa kepuasan merupakan prediktor utama dari loyalitas. Temuan studi-studi sebelumnya sudah sesuai dengan konsep Self-Regulating Processes yang dikemukakan oleh Bagozzi (1992), yakni bahwa setelah adanya pembentukan emosi yang diwakili kepuasan konsumen, maka hal itu akan menimbulkan aksi dalam bentuk loyalitas konsumen. Sehingga, semakin tinggi tingkat kepuasan yang dirasakan konsumen, semakin memicu loyalitas konsumen pada perusahaan bersangkutan. Dalam konteks perdagangan daring, kepuasan pelanggan dapat mengurangi niat untuk beralih ke merek lain, meningkatkan niat pembelian kembali, serta memicu gethok tular daring (Chang \& Wang, 2011). Studi oleh Anderson dan Srinivasan (2003) membuktikan hubungan kuat antara kepuasan dan loyalitas pada perdagangan daring. Namun demikian, ada temuan mengejutkan dari studi Sahadev dan Purani (2008) yang justru menyimpulkan bahwa kepuasan tidak mempengaruhi loyalitas. Karena dalam perdagangan daring, kepuasan yang dirasakan konsumen ternyata tidaklah cukup untuk membuat konsumen loyal. Terlalu banyaknya persaingan penawaran dan kemudahan transaksi pada perdagangan daring, mengkondisikan konsumen secara alami menjadi tidak mudah untuk merasa puas. Dengan demikian dapat dihipotesiskan sebagai berikut:

$\mathrm{H}_{2}$ : Kepuasan daring berpengaruh positif pada loyalitas daring.

Zeithaml et al., (2002) menegaskan bahwa penentu keberhasilan pada perdagangan daring bukan hanya karena harga produk yang murah, melainkan juga kualitas layanan daring. Loyalitas konsumen terjadi jika konsumen merasakan kepuasan baik atas produk yang dibeli maupun atas layanan daring yang diterima. Kualitas layanan, kepuasan, dan loyalitas merupakan tiga konsep yang saling berkaitan erat sebagaimana dikemukakan pada model Self-Regulating Processes yang diperkenalkan Bagozzi (1992). Studi oleh Chang dan Wang (2011) serta Cristobal et al. (2007), telah mengkonfirmasi hubungan antar dimensi-dimensi kualitas layanan dan loyalitas konsumen dalam konteks perdagangan daring. Temua studi mereka menunjukkan bahwa tidak terdapat hubungan secara langsung antara keduanya, konsumen perlu mengalami kepuasan terlebih dahulu, baru kemudian mereka akan menjadi loyal sebagai konsekuensi dari kualitas layanan yang diberikan perusahaan. Dengan demikian bisa dihipotesiskan sebagai berikut: $H_{3 a}:$ Kepuasan daring memediasi hubungan antara desain laman dan loyalitas daring. $H_{3 b}$ : Kepuasan daring memediasi hubungan antara reliabilitas dan loyalitas daring. $H_{3 c^{*}}$ : Kepuasan daring memediasi hubungan antara layanan pelanggan antara loyalitas daring. $H_{3 d}$ : Kepuasan daring memediasi hubungan antara privasi/keamanan pelanggan dan loyalitas daring. $H_{3 e}: \quad$ Kepuasan daring memediasi hubungan antara layanan pelanggan pasca pembelian dan loyalitas daring.

Teori ELM (Elaboration Likelihood Model) menjelaskan bahwa semakin tinggi tingkat keterlibatan produk yang dialami konsumen, semakin tinggi motivasi untuk memproses informasi terkaitdengan produk yang akan dibeli (Khare, 2014). Studi oleh Beatty dan Smith (1987) mengkonfirmasi bahwa konsumen dengan tingkat keterlibatan produk tinggi akan mengalokasikan lebih banyak waktu dan usaha untuk mencari informasi dan mengevaluasi produk yang akan dibeli. Alokasi waktu lebih banyak oleh konsumen menyebabkan konsumen akan lebih mendayagunakan bentuk-bentuk penawaran dari layanan penyedia produk 
sehingga kualitas layanan daring menjadi hal krusial dalam perdagangan daring. Berdasarkan paparan di atas maka dapat dihipotesiskan:

$H_{4 a}:$ Keterlibatan produk memperkuat hubungan antara desain laman dan kepuasan daring. $H_{4 b}$ : Keterlibatan produk memperkuat hubungan antara reliabilitas dan kepuasan daring. $H_{4 c^{\circ}}$ : Keterlibatan produk memperkuat hubungan antara layanan pelanggan dan kepuasan daring. $H_{4 d}:$ Keterlibatan produk memperkuat hubungan antara keamanan/privasi dan kepuasan daring. $H_{4 e}:$ Keterlibatan produk memperkuat hubungan antara layanan pelanggan pasca pembelian dan kepuasan daring.

Model penelitian mencakup dimensidimensi kualitas layanan daring yang terdiri dari desain laman, reliabilitas, layanan pelanggan, keamanan/privasi, serta layanan pelanggan pasca pembelian yang diyakini memiliki pengaruh positif pada kepuasan konsumen. Selanjutnya kepuasan konsumen dipercaya memiliki pengaruh positif pada loyalitas konsumen. Studi ini memodifikasi model penelitian Wolfinbarger dan Gilly (2003), Chang et al. (2009), Rolland dan Freeman (2010), dan Franco dan Cataluna (2009). Yakni dengan menggabungkan variabel- variabel kualitas layanan daring, kepuasan, dan loyalitas dalam perdagangan daring serta memasukkan variabel keterlibatan produk sebagai pemoderasi yang memperkuat pengaruh dimensi-dimensi kualitas layanan daring pada kepuasan konsumen. Model studi dari penelitian ini dapat dilihat pada Gambar 1.

\section{METODE PENELITIAN}

Studi menggunakan pendekatan kuantitatif dengan metode survei. Obyek penelitian adalah toko daring di Indonesia yakni mencakup toko daring mandiri (webstore) dan papan pasar daring (e-marketplace). Toko daring informal yang berbasis platform blog atau media sosial tidak termasuk dalam cakupan. Target populasi meliputi seluruh individu atau konsumen yang sudah melakukan pembelian produk secara daring. Studi menggunakan metode pengambilan sampel purposive sampling dengan kriteria unit sampel yakni konsumen berusia minimal 17 tahun, pernah melakukan belanja daring dalam satu tahun terakhir, dan pernah melakukan transaksi retur atau pengembalian uang (refund) akibat kegagalan layanan daring. Daerah sebaran

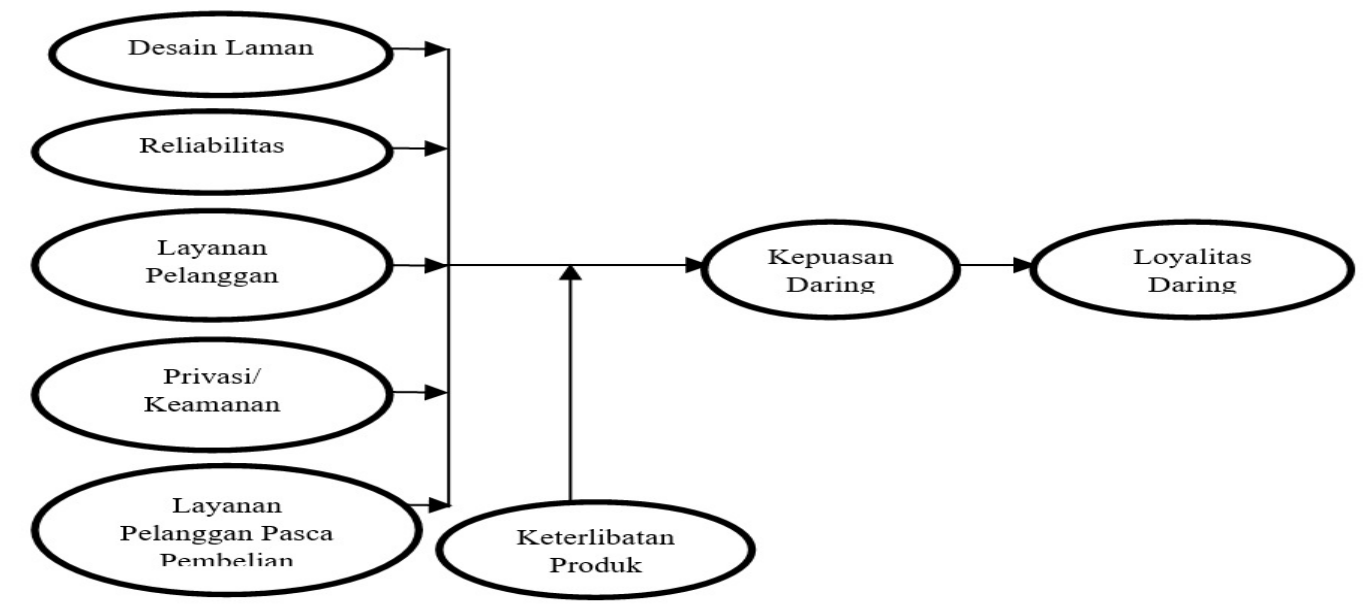

Gambar 1.

Model Studi

Sumber: Wolfinbarger dan Gilly (2003), Chang et al., (2009), Rolland dan Freeman (2010), dan

Franco dan Cataluña (2010) 
Tabel 1.

Definisi Operasional Variabel-Variabel Penelitian

\begin{tabular}{|c|c|c|}
\hline No & Variabel & Definisi Operasional \\
\hline 1 & $\begin{array}{l}\text { Desain } \\
\text { laman }\end{array}$ & $\begin{array}{l}\text { Persepsi konsumen terhadap kualitas desain laman yang } \\
\text { disediakan perusahaan, seperti: tampilan visual (tata } \\
\text { letak), informasi dan pembaharuannya, serta kemudahan } \\
\text { penggunaan dari laman tersebut. }\end{array}$ \\
\hline 2 & Reliabilitas & $\begin{array}{l}\text { Persepsi konsumen terhadap akurasi, konsistensi, dan } \\
\text { ketepatan layanan yang diberikan perusahaan sesuai } \\
\text { dengan yang telah dijanjikan }\end{array}$ \\
\hline 3 & $\begin{array}{l}\text { Layanan } \\
\text { pelanggan }\end{array}$ & $\begin{array}{l}\text { Persepsi konsumen terhadap kualitas daya tanggap dan } \\
\text { kontak perusahaan yang berfungsi untuk membantu } \\
\text { konsumen. }\end{array}$ \\
\hline 4 & $\begin{array}{l}\text { keamanan } \\
\text { atau privasi }\end{array}$ & $\begin{array}{l}\text { Persepsi konsumen terhadap sejauh mana laman } \\
\text { perusahaan aman dan mampu menjaga serta melindungi } \\
\text { informasi pelanggan. }\end{array}$ \\
\hline 5 & $\begin{array}{l}\text { Layanan } \\
\text { pelanggan } \\
\text { pasca } \\
\text { pembelian }\end{array}$ & $\begin{array}{l}\text { Persepsi konsumen terhadap kebijakan pengembalian } \\
\text { produk yang disebabkan oleh kegagalan perusahaan } \\
\text { memberikan layanan. }\end{array}$ \\
\hline 6 & $\begin{array}{l}\text { Kepuasan } \\
\text { Daring }\end{array}$ & $\begin{array}{l}\text { Perasaan pelanggan baik senang atau tidak senang pada } \\
\text { perusahaan sebagai hasil evaluasi pasca pembelian } \\
\text { terhadap kinerja layanan yang diberikan perusahaan. }\end{array}$ \\
\hline 7 & $\begin{array}{l}\text { Loyalitas } \\
\text { Daring }\end{array}$ & $\begin{array}{l}\text { Tingkat kesetiaan pelanggan pada perusahaan yang } \\
\text { direfleksikan pada niat pembelian ulang, kecenderungan } \\
\text { memberikan getok tular (WOM) positif, dan serta } \\
\text { kecenderungan melakukan tambahan pembelian dari } \\
\text { perusahaan yang sama. }\end{array}$ \\
\hline 8 & $\begin{array}{l}\text { Keterlibatan } \\
\text { Produk }\end{array}$ & $\begin{array}{l}\text { Tingkat keterlibatan konsumen pada sebuah produk } \\
\text { berdasarkan tingkat ketertarikan, nilai kesenangan, nilai } \\
\text { ketandaan pribadi, dan tingkat risiko terkait konsekuensi } \\
\text { kesalahan pembelian. }\end{array}$ \\
\hline
\end{tabular}


kuesioner sepenuhnya di wilayah Indonesia dengan pengumpulan data melalui saluran daring dan luring. Dari 278 kuesioner yang disebar, hanya 228 kuesioner yang bisa digunakan untuk analisis lebih lanjut karena faktor ketidaklengkapan pengisian.

Studi mengembangkan definisi operasional dari setiap variabel berbasis definisi konseptual sebagaimana dijelaskan pada Tabel 1. Skala pengukuran yang digunakan dalam penelitian ini yaitu skala likert dengan 5 (lima) kategori. Skala dimulai dari sangat tidak setuju (nilai 1) hingga sangat setuju (nilai 5).

Kemudian masing-masing variabel tersebut diukur dengan mengacu pada konsep pengukuran yang telah dilakukan oleh studistudi terdahulu sebagai berikut:1. Desain laman diukur dengan menggunakan 4 (empat) item pertanyaan dari studi Wolfinbarger dan Gilly (2003). 2. Reliabilitas diukur dengan menggunakan 3 (tiga) item pertanyaan dari studi Chang et al., (2009). 3. Layanan pelanggan

Tabel 2.

Pengujian Kualitas Data

\begin{tabular}{|c|c|c|c|c|c|c|}
\hline Variabel & $\begin{array}{l}\text { Rata- } \\
\text { rata }\end{array}$ & $\begin{array}{l}\text { Standar } \\
\text { Deviasi }\end{array}$ & Item-item & $\begin{array}{l}\text { Factor } \\
\text { Loading }\end{array}$ & $\begin{array}{l}\text { Average } \\
\text { Variance } \\
\text { Extracted }\end{array}$ & $\begin{array}{l}\text { Cronbach's } \\
\text { Alpha }\end{array}$ \\
\hline & & & KDS1 & 0,809 & & \\
\hline Desain & & & $\mathrm{KDS} 2$ & 0,802 & & \\
\hline \multirow[t]{3}{*}{ Laman } & 3,3465 & 0,96097 & $\mathrm{KDS} 3$ & 0,768 & 0,62 & 0,915 \\
\hline & & & KDS4 & 0,780 & & \\
\hline & & & KRE1 & 0,778 & & \\
\hline \multirow[t]{2}{*}{ Reliabilita } & 3,2456 & 1,07073 & KRE2 & 0,799 & 0,59 & 0,910 \\
\hline & & & KRE3 & 0,740 & & \\
\hline Layanan & & & KLP1 & 0,858 & & \\
\hline \multirow[t]{2}{*}{ Pelanggan } & 3,3114 & 0,98197 & KLP2 & 0,839 & 0,70 & 0,908 \\
\hline & & & KLP3 & 0,820 & & \\
\hline Keamanan/ & & & KPV1 & 0,797 & & \\
\hline Privasi & 3,2105 & 0,97523 & KPV2 & 0,779 & 0,62 & 0,741 \\
\hline Layanan & & & KLPP 1 & 0,819 & & \\
\hline Pasca & & & KLPP2 & 0,831 & & \\
\hline \multirow[t]{2}{*}{ Pembelian } & 3,1491 & 1,12428 & KLPP3 & 0,808 & 0,67 & 0,924 \\
\hline & & & KEP1 & 0,762 & & \\
\hline Kepuasan & & & KEP2 & 0,778 & & \\
\hline \multirow[t]{5}{*}{ Daring } & & & KEP3 & 0,851 & & \\
\hline & 3,2851 & 1,01198 & KEP4 & 0,812 & 0,65 & 0,963 \\
\hline & & & KEP5 & 0,813 & & \\
\hline & & & KEP6 & 0,836 & & \\
\hline & & & LOY1 & 0,589 & & \\
\hline Loyalitas & & & LOY2 & 0,619 & & \\
\hline \multirow[t]{4}{*}{ Daring } & & & LOY3 & 0,722 & & \\
\hline & 2,9912 & 0,95720 & LOY4 & 0,837 & 0,47 & 0,925 \\
\hline & & & LOY5 & 0,604 & & \\
\hline & & & LOY6 & 0,723 & & \\
\hline
\end{tabular}


Lanjutan Tabel 2.

Tabel 3.

Hasil Pengujian Hipotesis 1

\begin{tabular}{|c|c|c|c|c|c|c|}
\hline Variabel & $\begin{array}{l}\text { Rata- } \\
\text { rata }\end{array}$ & $\begin{array}{l}\text { Standar } \\
\text { Deviasi }\end{array}$ & Item-item & $\begin{array}{l}\text { Factor } \\
\text { Loading }\end{array}$ & $\begin{array}{l}\text { Average } \\
\text { Variance } \\
\text { Extracted }\end{array}$ & $\begin{array}{l}\text { Cronbach's } \\
\text { Alpha }\end{array}$ \\
\hline & & & KET2 & 0,526 & & \\
\hline Keterlibatan & & & KET3 & 0,536 & & \\
\hline \multirow[t]{6}{*}{ Produk } & & & KET5 & 0,529 & & \\
\hline & 3,2456 & 0,79715 & KET6 & 0,558 & 0,46 & 0,901 \\
\hline & & & KET7 & 0,784 & & \\
\hline & & & KET8 & 0,742 & & \\
\hline & & & KET9 & 0,842 & & \\
\hline & & & KET10 & 0,820 & & \\
\hline
\end{tabular}

Sumber: Data Primer (2016)

diukur dengan menggunakan 3 (tiga) item pertanyaan dari studi Chang et al., (2009). 4. Keamanan/privasi penelitian ini diukur dengan 3 (tiga) item pertanyaan dari studi Chang et al., (2009). 5. Layanan pelanggan pasca pembelian diukur dengan menggunakan 3 (tiga) item pertanyaan dari studi Rolland dan Freeman (2010). 6. Kepuasan daring diukur dengan 6 (enam) item pertanyaan dari studi Srinivasan dan Anderson (2003). 7. Loyalitas daring diukur dengan 4 (empat) item dari studi Kim et al., (2009) dan 2 (dua) item dari studi Gefen (2000). 8. Keterlibatan produk diukur dengan menggunakan 10 (sepuluh) item pertanyaan dari Kapferer dan Laurent (1985).

Studi melakukan uji validitas dan uji reliabilitas untuk memastikan akurasi dan konsistensi item-item pengukuran. Studi menggunakan metode uji validitas isi dan metode uji validitas konvergen melalui metode analisis faktor konfirmasi (Hair et al., 2010). Sedangkan untuk pengujian reliabilitas, studi menggunakan metode Cronbach Alpha.

Berdasarkan uji validitas konvergen, dari 38 item pengukuran, terdapat 3 item yang digugurkan. Kemudian berbasis nilai AVE (Average Variance Extracted), semua variabel terbukti memiliki tingkat validitas sangat baik kecuali pada variabel kepuasan daring dan loyalitas daring yang memiliki nilai AVE sedikit di bawah batas kritis 0,5. Kemudian untuk uji reliabilias, semua variabel memiliki nilai Cronbach Alpha di atas 0,6 sehingga memenuhi kriteria reliabilitas. Tabel 2 menunjukkan hasil pengujian validitas dan reliabilitas selengkapnya.

\section{HASIL DAN PEMBAHASAN}

Hipotesis 1a-e bertujuan untuk menguji pengaruh dimensi-dimensi kualitas layanan daring pada kepuasan daring. Mengacu pada Tabel 3, hipotesis H1a dan hipotesis H1d tidak didukung karena hasil analisis regresi menunjukkan pengaruh yang tidak signifikan $(p>0,05)$ dari variabel desain laman $(\beta=0,045)$ dan variabel keamanan/privasi $(\beta=0,075)$ pada variabel kepuasan daring. Sementara itu, hipotesis-hipotesis H1b, H1c, dan H1e didukung, karena hasil analisis regresi menunjukkan pengaruh variabel-variabel reliabilitas $(\beta=$ $0,368)$, layanan pelanggan $(\beta=0,164)$, dan layanan pelanggan pasca pembelian $(\beta=0,304)$ pada variabel kepuasan daring adalah terbukti signifikan $(p<0,05)$.

Temuan studi tersebut menunjukkan bahwa konsumen sangat memperhatikan reliabilitas, layanan pelanggan, dan layanan pelanggan pasca pembelian untuk menilai 
Tabel 3.

Hasil Pengujian Hipotesis 1

\begin{tabular}{lccl}
\hline \multicolumn{1}{c}{ Variabel Independen } & $\begin{array}{c}\text { Nilai Koefisien } \\
(\beta)\end{array}$ & Nilai t & Signifikansi \\
\hline Desain Laman & 0,045 & 0,740 & 0,460 \\
Reliabilitas & 0,368 & 6,362 & 0,000 \\
Layanan Pelanggan & 0,164 & 2,899 & 0,004 \\
Keamanan dan Privasi & 0,075 & 1,345 & 0,180 \\
LayananPasca Pembelian & 0,304 & 5,505 & 0,000 \\
\hline
\end{tabular}

Sumber: Data Primer (2016)

kepuasannya. Temuan pada variabel reliabilitas mendukung penelitian Chang et al., (2009) dan Santos (2003). Sedangkan temuan pada variabel layanan pelanggan mendukung penelitian Wolfinbarger dan Gilly (2003), Chang et al. (2009) dan Cristobal et al. (2007). Kemudian temuan pada variabel layanan pelanggan pasca pembelian mendukung penelitian Xing et al. (2010). Sementara itu temuan pada variabel desain laman ternyata berbeda dengan penelitian Wolfinbarger dan Gilly (2003); Lee dan Lin (2005); dan Kim et al. (2009). Perbedaan tersebut barangkali dikarenakan adanya perbedaan setting penelitian. Selanjutnya temuan pada variabel keamanan/privasi mendukung penelitian (Wolfinbarger \& Gilly, 2003), namun di sisi lain ternyata juga berbeda dengan penelitian Janda et al. (2002), Cristobal et al. (2007), dan Kim et al. (2009). Perbedaan tersebut barangkali selain disebabkan perbedaan setting penelitian ini, juga terdapat perbedaan metode pengambilan sampel. Kim et al. (2009) menggunakan metode convenience sampling sebagai metode pengambilan sampel, sedangkan penelitian ini menggunakan metode purposive sampling.

Berdasarkan Tabel 4 yang menunjukkan hasil analisis regresi kedua, hipotesis $\mathrm{H} 2$ didukung karena pengaruh kepuasan daring $(\beta=0,648)$ pada loyalitas daring adalah signifikan $(p<0,05)$. Temuan ini mendukung penelitian Anderson dan Srinivasan (2003) yang telah mengkonfirmasi pengaruh kepuasan daring pada loyalitas daring. Selain itu, penelitian ini juga mengkonfirmasi adanya teori sikap yang diperkenalkan Bagozzi (1992) yang menyatakan bahwa ekspresi emosi pelanggan yaitu kepuasan akan dilanjutkan dengan tindakan loyalitas yakni dalam bentuk kesediaan konsumen menjadikan perusahaan tersebut menjadi pilihan utama, serta bersedia merekomendasikannya kepada orang lain yang memerlukan.

Hipotesis 3a-e bertujuan untuk menguji peran kepuasan daring sebagai variabel pemediasi pada hubungan antara dimensidimensi kualitas layanan daring dan loyalitas daring. Tabel 5 menunjukkan hasil analisis regresi 3a-e yang terdiri dari 3 tahapan analisis. Kesimpulan dari hasil analisis regresi diperoleh dengan mengevaluasi setiap tahapan sebagai syarat yang harus dipenuhi dalam pengujian mediasi menurut Baron dan Kenny (1986).

Pada tahap pertama, hasil analisis regresi mengkonfirmasi pengaruh reliabilitas $(\beta=0,368)$, layanan pelanggan $(\beta=0,164)$, dan layanan pelanggan pasca pembelian $((\beta=$ $0,304)$ pada kepuasan daring adalah signifikan $(p<0,05)$. Pada tahap kedua, hasil analisis regresi 
Tabel 4.

Hasil Pengujian Hipotesis 2

\begin{tabular}{lccl}
\hline Variabel & Nilai Koefisien $(\beta)$ & Nilai t & Signifikansi \\
\hline Kepuasan Daring & 0,648 & 12,803 & 0,000 \\
\hline Nilai Adjusted $R^{2}=0,418$ & & \\
\hline
\end{tabular}

\section{Sumber: Data Primer (2016)}

membuktikan pengaruh reliabilitas $(\beta=0,283)$, layanan pelanggan $(\beta=0,120)$, dan layanan pelanggan pasca pembelian $(\beta=0,325)$ pada loyalitas daring adalah signifikan $(\mathrm{p}<0,05)$. Pada tahap ketiga, hasil analisis regresi menunjukkan pengaruh layanan pelanggan pada loyalitas daring menjadi tidak signifikan $(\mathrm{p}>0,05)$ dan selanjutnya menjadi bukti kuat bahwa kepuasan daring memediasi penuh hubungan antara layanan pelanggan dan loyalitas daring. Hasil analisis regresi selanjutnya, pengaruh reliabilitas dan layanan pelanggan pasca pembelian pada loyalitas daring tetap signifikan $(p<0,05)$ dengan penurunan nilai koefisien $\beta$ jika dibandingkan dengan hasil analisis regresi tahap kedua.

Hal ini menjadi bukti bahwa kepuasan daring memediasi secara parsial pengaruh reliabilitas dan layanan pelanggan pasca pembelian pada loyalitas daring. Dengan demikian hipotesis-hipotesis $\mathrm{H} 3 \mathrm{~b}, \mathrm{H} 3 \mathrm{c}$, dan H3e didukung. Sementara itu, hipotesis H3a dan hipotesis H3d tidak didukung, karena hasil analisis regresi pada tahap pertama saja sudah menunjukkan hasil yang tidak signifikan untuk pengaruh variabel desain laman dan keamanan/ privasi pada kepuasan daring $(p>0,05)$.

Hipotesis 4a-e akan menguji peran keterlibatan produk sebagai variabel pemoderasi pada hubungan antara dimensi-dimensi kualitas layanan daring dan kepuasan daring. Studi menggunakan metode pengujian kelompok bagian (sub group) melalui Uji Chow. Uji Chow merupakan alat analisis yang digunakan untuk mengetahui apakah terdapat perbedaan pengaruh pada hubungan antar variabel dalam dua periode berbeda (Gujarati, 1995). Pada studi ini, analisis dua periode dianalogikan dengan dua tingkatan keterlibatan produk, yaitu keterlibatan produk tinggi dan keterlibatan produk rendah. Hasil penelitian mengenai peran keterlibatan produk sebagai pemoderasi selengkapnya ditampilkan pada Tabel 6.

Hipotesis 4a merumuskan peran moderasi keterlibatan produk dalam memperkuat pengaruh desain laman pada kepuasan daring. Hasil uji chow antara tingkat keterlibatan produk tinggi dan rendah pada Tabel 6 menunjukkan angka F-hitung senilai 8,70 lebih besar daripada angka F-kritis $\left(\alpha=5\right.$ persen, $\left.\mathrm{df}_{3,222}\right)$ senilai 2,65. Dengan demikian hipotesis 4 a didukung.

Hipotesis $4 \mathrm{~b}$ merumuskan peran moderasi dari keterlibatan produk dalam memperkuat pengaruh reliabilitas pada kepuasan daring. Hasil uji chow antara tingkat keterlibatan produk rendah dan tinggi pada Tabel 6 menunjukkan angka F-hitung senilai 8,29 lebih besar daripada angka F-kritis $(\alpha=5$ persen, $\mathrm{df}_{3,222}$ ) senilai 2,65. Dengan demikian hipotesis $4 \mathrm{~b}$ didukung.

Hipotesis 4c merumuskan peran moderasi keterlibatan produk dalam memperkuat pengaruh layanan pelanggan pada kepuasan daring. Hasil uji chow antara tingkat keterlibatan produk tinggi dan rendah pada Tabel 6 menunjukkan angka F-hitung senilai 12,07 lebih besar daripada angka $F$ kritis $(\alpha=5$ persen, $\mathrm{df}_{3,222}$ ) senilai 2,65. Dengan demikian hipotesis $4 \mathrm{c}$ didukung.

Hipotesis 4d merumuskan peran moderasi keterlibatan produk dalam memperkuat pengaruh keamanan/privasi pada kepuasan daring. Hasil uji chow antara tingkat keterlibatan produk tinggi dan rendah pada 
Tabel 5.

Hasil Pengujian Hipotesis 3a-e

\begin{tabular}{cccc}
\hline \multicolumn{4}{c}{ Hasil Regresi Variabel Independen terhadap Kepuasan Daring (Tahap I) } \\
\hline Variabel Independen & Nilai & Nilai t & Signifikansi \\
Koefisien $(\beta)$ & & \\
Desain Laman & 0,045 & 0,740 & 0,460 \\
Reliabilitas & 0,368 & 6,362 & 0,000 \\
Layanan Pelanggan & 0,164 & 2,899 & 0,004 \\
Keamanan dan Privasi & 0,075 & 1,345 & 0,180 \\
Layanan Pasca Pembelian & 0,304 & 5,505 & 0,000 \\
\hline Hasil Regresi Variabel Independen terhadap Loyalitas Daring (Tahap II) \\
\hline Variabel Independen & Nilai & Nilai t & Signifikansi \\
& Koefisien ( $\beta$ ) & & \\
Desain Laman & 0,111 & 1,752 & 0,081 \\
Reliabilitas & 0,283 & 4,662 & 0,000 \\
Layanan Pelanggan & 0,120 & 2,021 & 0,044 \\
Keamanan dan Privasi & 0,066 & 1,116 & 0,266 \\
Layanan Pasca Pembelian & 0,325 & 5,616 & 0,000
\end{tabular}

Hasil Regresi Variabel Independen terhadap Loyalitas Daring dimediasi

Kepuasan Daring (Tahap III)

\begin{tabular}{cccc}
\hline Variabel Independen & $\begin{array}{c}\text { Nilai } \\
\text { Koefisien }(\beta)\end{array}$ & Nilai t & Signifikansi \\
Desain Laman & 0,094 & 1,585 & 0,114 \\
Reliabilitas & 0,139 & 2,267 & 0,024 \\
Layanan Pelanggan & 0,056 & 0,994 & 0,321 \\
Keamanan dan Privasi & 0,036 & 0,659 & 0,511 \\
Layanan Pasca Pembelian & 0,206 & 3,595 & 0,000 \\
Kepuasan Daring & 0,391 & 5,965 & 0,000 \\
\hline
\end{tabular}

Sumber: Data Primer (2016) 
Tabel 6.

Tes Chow Untuk Pengujian Hipothesis 4a-e

\begin{tabular}{|c|c|c|c|c|c|c|}
\hline No & $\begin{array}{l}\text { Model } \\
\text { Regresi }\end{array}$ & $\begin{array}{l}\text { Desain } \\
\text { Laman }\end{array}$ & Reliabilitas & $\begin{array}{l}\text { Layanan } \\
\text { Pelanggan }\end{array}$ & $\begin{array}{c}\text { Keamanan/ } \\
\text { Privasi }\end{array}$ & $\begin{array}{c}\text { Layanan } \\
\text { Pelanggan } \\
\text { Pasca } \\
\text { Pembelian }\end{array}$ \\
\hline 1 & Gabungan & $\begin{array}{l}\hat{\mathrm{Y}}_{\mathrm{t}}=1,793+ \\
0,446 \mathrm{X}_{\mathrm{t}} \\
\mathrm{S}_{1}=190,785 \\
\mathrm{df}=226\end{array}$ & $\begin{array}{l}\hat{\mathrm{Y}}_{\mathrm{t}}=1,589+ \\
0,523 \mathrm{X}_{\mathrm{t}} \\
\mathrm{S}_{1}=161,361 \\
\mathrm{df}=226\end{array}$ & $\begin{array}{l}\hat{\mathrm{Y}}_{\mathrm{t}}=1,852+ \\
0,433 \mathrm{X}_{\mathrm{t}} \\
\mathrm{S}_{1}=191,448 \\
\mathrm{df}=226\end{array}$ & $\begin{array}{l}\hat{\mathrm{Y}}_{\mathrm{t}}=1,972+ \\
0,409 \mathrm{X}_{\mathrm{t}} \\
\mathrm{S}_{1}=196,342 \\
\mathrm{df}=226\end{array}$ & $\begin{array}{l}\hat{\mathrm{Y}}_{\mathrm{t}}=1,866+ \\
0,451 \mathrm{X}_{\mathrm{t}} \\
\mathrm{S}_{1}=174,196 \\
\mathrm{df}=226\end{array}$ \\
\hline 2 & $\begin{array}{l}\text { Tingkat } \\
\text { Keterlibatan } \\
\text { Produk } \\
\text { Tinggi }\end{array}$ & $\begin{array}{l}\hat{Y}_{t}=2,873+ \\
0,213 X_{t} \\
S_{2}=87,296 \\
d f=118\end{array}$ & $\begin{array}{l}\hat{\mathrm{Y}}_{\mathrm{t}}=2,272+ \\
0,396 \mathrm{X}_{\mathrm{t}} \\
\mathrm{S}_{2}=71,693 ; \mathrm{df} \\
=118\end{array}$ & $\begin{array}{l}\hat{\mathrm{Y}}_{\mathrm{t}}=2,902+ \\
0,212 \mathrm{X}_{\mathrm{t}} \\
\mathrm{S}_{2}=86,479 \\
\mathrm{df}=118\end{array}$ & $\begin{array}{l}\hat{\mathrm{Y}}_{\mathrm{t}}=2,878+ \\
0,223 \mathrm{X}_{\mathrm{t}} \\
\mathrm{S}_{2}=85,955 \\
\mathrm{df}=118\end{array}$ & $\begin{array}{l}\hat{\mathrm{Y}}_{\mathrm{t}}=2,612+ \\
0,302 \mathrm{X}_{\mathrm{t}} \\
\mathrm{S}_{2}=79,645 \\
\mathrm{df}=118\end{array}$ \\
\hline 3 & $\begin{array}{l}\text { Tingkat } \\
\text { Keterlibatan } \\
\text { Produk } \\
\text { Rendah }\end{array}$ & $\begin{array}{l}\hat{\mathrm{Y}}_{\mathrm{t}}=1,335+ \\
0,509 \mathrm{X}_{\mathrm{t}} \\
\mathrm{S}_{3}=83,410 \\
\mathrm{df}=106\end{array}$ & $\begin{array}{l}\hat{\mathrm{Y}}_{\mathrm{t}}=1,233+ \\
0,547 \mathrm{X}_{\mathrm{t}} \\
\mathrm{S}_{3}=71,286 \\
\mathrm{df}=106\end{array}$ & $\begin{array}{l}\hat{\mathrm{Y}}_{\mathrm{t}}=1,140+ \\
0,562 \mathrm{X}_{\mathrm{t}} \\
\mathrm{S}_{3}=78,128 \\
\mathrm{df}=106\end{array}$ & $\begin{array}{l}\hat{\mathrm{Y}}_{\mathrm{t}}=1,461+ \\
0,480 \mathrm{X}_{\mathrm{t}} \\
\mathrm{S}_{3}=87,694 \\
\mathrm{df}=106\end{array}$ & $\begin{array}{l}\hat{\mathrm{Y}}_{\mathrm{t}}=1,523+ \\
0,478 \mathrm{X}_{\mathrm{t}} \\
\mathrm{S}_{2}=76,992 \\
\mathrm{df}=106\end{array}$ \\
\hline 4 & $\begin{array}{l}\text { F-hitung } \\
\mathrm{n} 1=120 \\
\mathrm{n} 2=108 ; \\
\mathrm{k}=3\end{array}$ & $\begin{array}{l}\mathrm{F}=\left(\mathrm{S}_{5} / \mathrm{k}\right) / \\
\left(\mathrm{S}_{4} /\left(\mathrm{n}_{1}+\mathrm{n}_{2-}\right.\right. \\
2 \mathrm{k}))=8,70\end{array}$ & $\begin{array}{l}\mathrm{F}=\left(\mathrm{S}_{5} / \mathrm{k}\right) / \\
\left(\mathrm{S}_{4} /\left(\mathrm{n}_{1}+\mathrm{n}_{2}-\right.\right. \\
2 \mathrm{k})) \\
\quad=9,51\end{array}$ & $\begin{array}{l}\mathrm{F}=\left(\mathrm{S}_{5} / \mathrm{k}\right) / \\
\left(\mathrm{S}_{4} /\left(\mathrm{n}_{1}+\mathrm{n}_{2}-\right.\right. \\
2 \mathrm{k})) \\
\quad=12,07\end{array}$ & $\begin{array}{l}\mathrm{F}=\left(\mathrm{S}_{5} / \mathrm{k}\right) / \\
\left(\mathrm{S}_{4} /\left(\mathrm{n}_{1}+\mathrm{n}_{2-}\right.\right. \\
2 \mathrm{k})) \\
\quad=9,67\end{array}$ & $\begin{array}{l}\mathrm{F}=\left(\mathrm{S}_{5} / \mathrm{k}\right) / \\
\left(\mathrm{S}_{4} /\left(\mathrm{n}_{1}+\mathrm{n}_{2-}\right.\right. \\
2 \mathrm{k})) \\
\quad=8,29\end{array}$ \\
\hline 5 & $\begin{array}{l}\text { Perhitungan } \\
\text { F-kritis }\end{array}$ & F kritis & $-2 \mathrm{k})=\mathrm{F} \mathrm{kr}$ & $\%, 3,222)$ & & \\
\hline
\end{tabular}

Sumber: Data Primer (2016)

Tabel 6 menunjukkan angka F-hitung senilai 9,67 lebih besar daripada angka F-kritis ( $\alpha=5 \%$, $\mathrm{df}_{3,222}$ ) senilai 2,65. Dengan demikian hipotesis $4 \mathrm{~d}$ didukung.

Hipotesis 4e merumuskan peran moderasi keterlibatan produk dalam memperkuat pengaruh layanan pelanggan pasca pembelian pada kepuasan daring. Hasil uji chow antara tingkat keterlibatan produk tinggi dan rendah pada Tabel 6 menunjukkan angka F-hitung senilai 8,29 dan angka F-kritis $\left(\alpha=5 \%\right.$, df ${ }_{3}$, ${ }_{222}$ ) senilai 2,65. Dengan demikian hipotesis $4 \mathrm{e}$ didukung.

\section{SIMPULAN DAN SARAN}

Berdasarkan temuan-temuan studi yang diperoleh dapat disimpulkan sebagai berikut. Pertama, hanya 3 (tiga) dimensi kualitas layanan daring yakni reliabilitas, layanan pelanggan, dan layanan pelanggan pasca pembelian yang terbukti berpengaruh positif pada kepuasan daring. Studi ini mengkonfirmasi tidak terjadinya pengaruh desain laman dan keamanan/privasi pada kepuasan daring, namun demikian perhatian besar dari perusahaan tetap perlu diberikan pada kedua dimensi bersangkutan. Kedua, 
kepuasan berpengaruh positif pada loyalitas konsumen. Kepuasan yang dirasakan konsumen tersebut akan membuat konsumen loyal. Bentuk loyalitas yang diberikan konsumen terhadap perusahaan sebagai penyedia produk dapat berupa niat untuk melakukan pembelian kembali dan bersedia untuk merekomendasi pada kerabat dekat, serta menjadikan perusahaan tersebut sebagai perusahaan favoritnya. Ketiga, kepuasan daring berhasil memediasi pengaruh reliabilitas, layanan pelanggan, dan layanan pelanggan pasca pembelian pada loyalitas daring. Sedangkan untuk pengaruh desain laman dan keamanan/privasi pada loyalitas daring, kepuasan daring gagal melakukan peran mediasi. Keempat, keterlibatan produk dalam penelitian ini dikonfimasi sebagai pemoderasi yang memperkuat pengaruh semua dimensi kualitas layanan daring yakni desain laman, reliabilitas, layanan pelanggan, keamanan/ privasi, dan layanan pelanggan pasca pembelian pada kepuasan daring.

\section{REFERENSI}

Castaneda JA, Rodriguez MA, Luque T. 2009. Attitudes' Hierarchy of Effects in Online User Behavior", Online Information Review. Vol. 33 (1): 7-21.

Chang HH, Chen, SW. 2009. Consumer Perception Of Interface Quality, Security, and Loyalty in Electronic Commerce. Information \& Management. Vol. 46 (7): 411-417.

Chang HH, Wang YH, Yang WY. 2009. The Impact of E-Service Quality, Customer Satisfaction and Loyalty on E-Marketing: Moderating Effect of Perceived Value. Total Quality Management \& Business Excellence. Vol. 20 (4): 423-443.

Chang HH, Wang HW. 2011. The Moderating Effect Of Customer Perceived Value On Online Shopping Behaviour. Online Information Review. Vol. 35 (3): 333359.
Dharmesti MDD, Nugroho SS. 2012. The Antecedents of Daring Customer Satisfaction and Customer Loyalty. The Business \&Management Review. Vol. 3 (1): 37-46. Franco MJS, Cataluna FJR. 2010. Virtual Travel Communities and Customer Loyalty: Customer Purchase Involvement and Web Site Design. Electronic Commerce Research and Applications. Vol.9: 171182

Ha JY, Jang SC. 2009. Perceived Justice In Service Recovery and Behavioral Intentions: the Role of Relationship Quality. International Journal of Hospitality Management. Vol 28 (3): 319-327.

Hair JF, William CB, Barry JB, Rolph EA. 2010. Multivariate Data Analysis: A Global Perspective. Seventh Edition. Upper Saddle River: Pearson

Hong IB. 2015. Understanding The Consumer's Daring Merchant Selection Process: Theroles of Product Involvement, Perceived Risk, and Trust Expectation. International Journal of Information Management. Vol. 35: 322-336.

Jayawardhena C, Wright LT. 2009. An Empirical Investigation into E-Shopping Excitement: Antecedents and Effects. European Journal of Marketing. Vol. 43 (9): 1171-1187.

Khare A. 2014. Consumers' Susceptibility to Interpersonal Influence as a Determining Factor of Ecologically Conscious Behaviour. Marketing Intelligence \& Planning. Vol. 32 (1): 2-20.

Kim JH, Kim M, Kandampully J. 2009. Buying Environment Characteristics In the Context of E-Service. European Journal of Marketing. Vol. 43 (9/10): 1188- 1203. $\mathrm{Li}$ Y, Xu L, Li D. 2013. Examining Relationships between the Return 
Policy, Product Quality, and Pricing Strategy in Online Direct Selling. International Journal of Production Economics. Vol. 144 (2): 451-460. Mattila AS. 2010. DoWomen Like Options More Than Men? an Examination in the Context of Service Recovery. Journal of Services Marketing. Vol. 24 (7): 499-508.

Piercy, N. 2014. Online Service Quality: Content and Process of Analysis. Journal of Marketing Management. Vol. 30 (7/8): 747-785.

Rolland S, Freeman I. 2010. A New Measure Of E-Service Quality In France. International Journal of Retail \& Distribution Management. Vol. 38 (7): $497-517$.

Sakhaei SF, Afshari AJ, Esmaili E. 2014. The Impact of Service Quality on Customer Satisfaction in Internet Banking. Journal of Mathematics and Computer Sains. Vol. 9: 33-40.

Sengupta AS, Balaji MS, Krishnan BC. 2015. How Customer Cope with Service Failure? A Study of Brand Reputation and Customer Satisfaction. Journal of Business Researh. Vol. 68 (3): 665-674.

Xing Y, GrantDB, McKinnon AC, Fernie J. 2010. Physical Distribution Service Quality in Online Retailing. International Journal of Physical Distribution \& Logistics Management. Vol. 40 (5): $415-432$.

.2019. Top Sites in Indonesia. Tersedia pada: http://www.alexa.com/ topsites/countries/ID. Diakses pada tanggal 7 Agustus 2019. 